\title{
Quantitative observation of cyanobacteria and diatoms from space using PhytoDOAS on SCIAMACHY data
}

\author{
A. Bracher ${ }^{1,2}$, M. Vountas ${ }^{2}$, T. Dinter ${ }^{2}$, J. P. Burrows ${ }^{2,3}$, R. Röttgers ${ }^{4}$, and I. Peeken ${ }^{5,1}$ \\ ${ }^{1}$ Alfred-Wegener-Institute for Polar and Marine Research, Bussestr. 24, 27570 Bremerhaven, Germany \\ ${ }^{2}$ Institute of Environmental Physics, University of Bremen, Otto-Hahn-Allee 1, 28359 Bremen, Germany \\ ${ }^{3}$ currently at: Centre for Ecology and Hydrology Maclean Building, Benson Lane, Crowmarsh Gifford, Wallingford, \\ Oxfordshire, OX10 8BB, UK \\ ${ }^{4}$ Institute of Coastal Research, GKSS Research Center Geesthacht, Max-Planck.Strasse 1, 21502 Geesthacht, Germany \\ ${ }^{5}$ MARUM - Center for Marine Environmental Sciences, Bremen, Germany
}

Received: 7 October 2008 - Published in Biogeosciences Discuss.: 28 November 2008

Revised: 30 March 2009 - Accepted: 6 April 2009 - Published: 6 May 2009

\begin{abstract}
In this study the technique of Differential Optical Absorption Spectroscopy (DOAS) has been adapted for the retrieval of the absorption and biomass of two major phytoplankton groups (PhytoDOAS) from data of the Scanning Imaging Absorption Spectrometer for Atmospheric Chartography (SCIAMACHY) satellite sensor. SCIAMACHY measures back scattered solar radiation in the UV-Vis-NIR spectral regions with a high spectral resolution $(0.2$ to $1.5 \mathrm{~nm})$. In order to identify phytoplankton absorption characteristics in the SCIAMACHY data in the range of 430 to $500 \mathrm{~nm}$, phytoplankton absorption spectra measured in-situ during two different RV "Polarstern" expeditions were used. The two spectra have been measured in different ocean regions where different phytoplankton groups (cyanobacteria and diatoms) dominated the phytoplankton composition. Results clearly show distinct absorption characteristics of the two phytoplankton groups in the SCIAMACHY spectra. Using these results in addition to calculations of the light penetration depth derived from DOAS retrievals of the inelastic scattering (developed by Vountas et al., 2007), globally distributed pigment concentrations for these characteristic phytoplankton groups for two monthly periods (FebruaryMarch 2004 and October-November 2005) were determined. This satellite information on cyanobacteria and diatoms distribution clearly matches the concentrations based on high pressure liquid chromatography (HPLC) pigment analysis of collocated water samples and concentrations derived from a
\end{abstract}

Correspondence to: A. Bracher (astrid.bracher@awi.de) global model analysis with the NASA Ocean Biogeochemical Model (Gregg et al., 2003; Gregg and Casey 2007). The quantitative assessment of the distribution of key phytoplankton groups from space enables various biogeochemical regions to be distinguished and will be of great importance for the global modeling of marine ecosystems and biogeochemical cycles which enables the impact of climate change in the oceanic biosphere to be estimated.

\section{Introduction}

Phytoplankton plays an important role in the global carbon cycle via the fixation of inorganic carbon during photosynthesis and its export to the deep sea by subsequent sinking of organic particles. The intensity of both carbon fixation and export is, however, strongly dependent on the size and composition of cells in addition to the overall structure of the trophic community. Differences in phytoplankton composition reflect a broader suite of associated differences in autotrophic and heterotrophic interactions. For example, diatom dominated communities tend to be associated with higher export of organic carbon (Buesseler, 1998), as compared to cyanobacteria dominated communities, which are characteristic of ecosystems with efficient regeneration of nutrients and low export (Waterbury et al., 1986). Thus, monitoring spatial and temporal variations of the distribution of dominant phytoplankton functional types (PFTs) at a global scale is of critical importance for modeling studies.

Published by Copernicus Publications on behalf of the European Geosciences Union. 


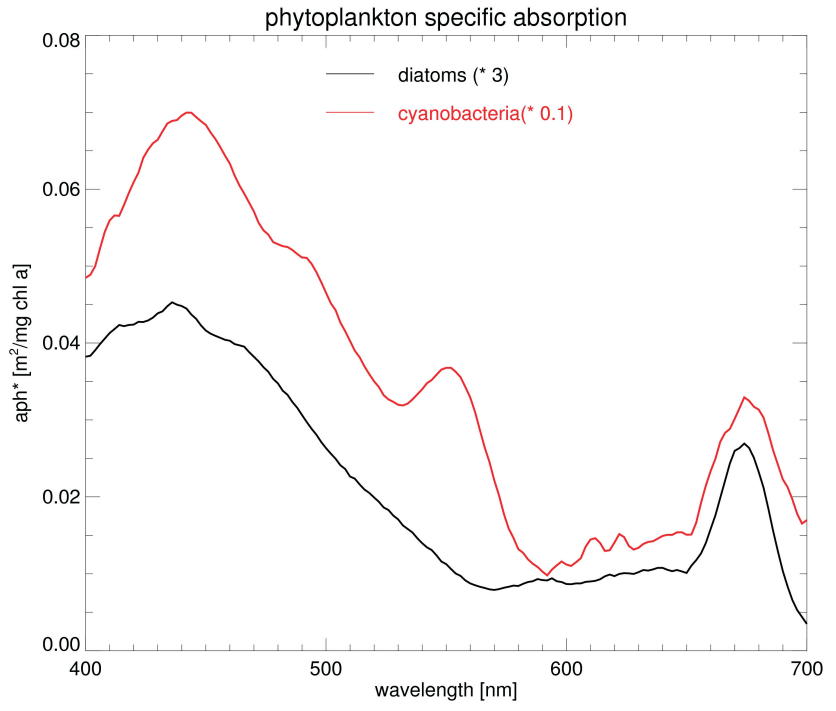

Fig. 1. Spectra of pigment-specific phytoplankton absorption determined in water samples of two different ship cruises with RV Polarstern within the Atlantic Ocean: A phytoplankton absorption spectrum of a phytoplankton community dominated by over $80 \%$ diatoms measured during EIFEX cruise (ANTXXI-3) on 14 March 2004 at $46^{\circ} \mathrm{S}$ and $9^{\circ} \mathrm{W}$ (diatoms=black) scaled by the factor of 3 and a spectrum from a phytoplankton community with only cyanobacteria (red) measured during ANTXXIII-1 cruise on 29 October 2005 at $23^{\circ} \mathrm{N}$ and $22^{\circ} \mathrm{W}$ and scaled by factor 0.1 .

Observations of the backscattered solar radiation above the oceans by instrumentation on satellite platforms, so-called ocean color data, provide the opportunity to assess globally the marine phytoplankton biomass (e.g. O'Reilly et al., 1998). This is then used to model global distributions of phytoplankton primary production (Behrenfeld and Falkowski, 1997). Several of the current generation of global numerical models, which are used to estimate the efficiency of the marine biological pump, represent independently the main phytoplankton groups (e.g. Gregg et al., 2003; Le Quere et al., 2005; Moore et al., 2004). However, global quantitative information on the distribution of the major phytoplankton groups for these models is still lacking.

Since certain phytoplankton groups are generally characterized by some diagnostic pigments (Jeffrey and Vesk, 1997), the chl-a normalized phytoplankton absorptions differ in magnitude and spectrum due to phytoplankton composition (e.g. Sathyendranath et al., 1987; Hoepffner und Sathyendranath, 1991; Bracher und Tilzer, 2001; Ciotti et al., 2002; see Fig. 1 as well). However, the absorption spectrum can also be modified by variations in pigment packaging (described by Kirk, 1994) and molecular interactions of pigment molecules in their corresponding pigmentprotein complexes (Johnsen et al., 1994). Satellite retrievals of information about the distribution of certain phytoplankton groups have been successfully applied using bio-optical models that account for the specific optical properties of species such as coccolithophorids (e.g. Brown and Yoder, 1994), diatoms (Cota et al., 2003; Sathyendranath et al., 2004), the cyanobacteria Synechococcus (Morel, 1997) and $\mathrm{N}_{2}$-fixing cyanobacteria Trichodesmium (Subramaniam, et al., 2002).

Several recent studies have attempted to retrieve information about multiple types of PFTs. Some studies used the approach of identifying different size classes (micro-, nano-, and picoplankton) as a first indication for the occurrence of different biogeochemical indicators. In these studies, up to three size classes of phytoplankton in open ocean waters have been derived by algorithms, which were based on the bio-optical relationships determined from a large bio-optical and pigment in-situ data set; some were developed for certain oceanic regions (Aiken et al., 2007, Raitsos et al., 2008). Also models have been developed to retrieve global distributions from ocean color data (Devred et al., 2006; Uitz et al., 2006; Hirata et al., 2008). The Aiken et al. (2007) approach was applied to Medium Resolution Imaging Spectrometer (MERIS) data from the Southern Benguela ecosystem only. This method uses bio-optical traits retrieved from a complex in-situ data set measured during one cruise to classify phytoplankton into three size classes, and then backscattering characteristics to subdivide the size classes into functional types. In addition, another method was developed in which the size distribution was further enhanced to retrieve certain ecotypes, e.g., Synechococcus-like-cyanobacteria versus Prochlorophytes, both belonging to the picoplankton. This algorithm described in Alvain et al. (2005), optimized in Alvain et al., (2008) and known as PHYSAT was applied to Sea-viewing-Wide-Field-of-View-Sensor (SeaWiFS) data and yielded global distributions of five major dominant phytoplankton groups. All the above mentioned approaches, except for the method by Uitz et al. (2006), only identify the dominant PFTs or size class. Uitz et al. (2006) developed a parameterization of a large global and depth-resolved HPLC data-base to derive from SeaWiFS chl-a directly - the vertically resolved chl-a concentration of all three size classes. However, none of these prior approaches yields quantitative estimates of PFT abundance from satellite observations. The objective of this study is to separate different phytoplankton groups from spectrally resolved satellite observations of the backscattered solar radiation from the top of the atmosphere.

The satellite sensor SCIAMACHY flies onboard the European satellite ENVISAT and was launched on the 28th February 2002. It measures the UV-VIS-NIR electromagnetic radiation backscattered from the top of the atmosphere at high spectral resolution. SCIAMACHY was designed and is mainly used to derive geophysical information about the trace constituent composition of the Earth's atmosphere. However, a secondary objective was the observation and interpretation of ocean color. 
Vountas et al. (2007) showed that it is possible to identify phytoplankton absorption in the SCIAMACHY backscattered solar radiation measurements by using the Differential Optical Absorption (DOAS) method. The differential absorption of each molecular absorber within a selected wavelength window is retrieved and this yields the slant columns of the absorbers along the optical path of the up-welling solar backscattered electromagnetic radiation. In this study, the phytoplankton absorption of a community with a well mixed species composition was identified and retrieved from the satellite observations. In addition, these data were analyzed to derive the amount of phytoplankton along the effective under-water light path observed by SCIAMACHY by additionally exploiting the signal from vibrational Raman scattering by water molecules within the UV-A range of the spectrum. By that, global phytoplankton biomass concentrations (chl-a) were derived which compared well overall with case I chl-a of the Moderate Resolution Imaging Spectroradiometer (MODIS) ocean color data.

As part of the study presented here, the DOAS method was used and modified for identification of the specific absorption signatures of two biogeochemical contrasting phytoplankton groups, the cyanobacteria and diatoms. The method herein referred to as PhytoDOAS. Globally distributed pigment concentrations for these characteristic phytoplankton groups for two monthly periods within 2004 and 2005 were derived. These satellite retrieved phytoplankton group distributions were compared to in-situ measurements and model calculations. Section 2 describes the satellite instrument, the PhytoDOAS retrieval and the method of in situ measurements used as reference spectra and for first comparisons. In Sect. 3, the global satellite maps of diatoms and cyanobacteria and comparisons to in-situ and global model estimations are presented. The results are discussed in relation to other estimates of phytoplankton group distributions in Sect. 4, which ends with the main conclusions and future prospects for the PhytoDOAS method.

\section{Instrumentation and methods}

\subsection{Satellite Sensor SCIAMACHY and principles of re- trieval technique DOAS}

SCIAMACHY (Scanning Imaging Absorption Spectrometer for Atmospheric CHartographY; described in more detail in Burrows et al., 1995; Bovensmann et al., 1999) is mounted on board ESA's ENVIronmental SATellite, ENVISAT, which was launched in 2002. The sun-synchronous, near-polar orbit of ENVISAT has a local equator crossing time of 10:00 a.m. in a descending node. The instrument measures transmitted, scattered and reflected light from the Earth's atmosphere or surface, observing in nadir and limb viewing geometries spanning from the UV to the near infrared at high spectral resolution (in the UV-Vis.: $0.26-0.44 \mathrm{~nm}$ ). The alter- nate limb and nadir viewing, coupled with a swath width of $960 \mathrm{~km}$, yields global coverage at the equator within six days. This study exclusively uses spectra measured in nadir viewing from 340 to $390 \mathrm{~nm}$ and 425 to $500 \mathrm{~nm}$. Because of limbnadir geometries alternating in SCIAMACHY, the nadir scan along-track is therefore intermittent.

Although SCIAMACHY is primarily an atmospheric mission, part of the detected solar radiation penetrates the ocean surface and is consequently influenced by the absorption and backscattering properties of the upper ocean. The signalto-noise ratio of SCIAMACHY at 340 to $500 \mathrm{~nm}$ is above 2000 (Bovensmann et al., 1999) in each spectral bin of 0.2 to $0.4 \mathrm{~nm}$ width. This is more sensitive than the value of 1650 for the broadband wavebands in similar spectral regions of the well calibrated MERIS ocean color sensor (Bezy et al., 2000). The draw-back of the high spectral resolution is a rather large pixel size of $30 \mathrm{~km}$ by $30 \mathrm{~km}$ at best. Because of this, and the rather low temporal resolution because of the alternating nadir-limb viewing of SCIAMACHY, the ocean color application to these data are limited to the open ocean and necessitates analyses over longer time periods than conventional ocean color sensors. The radiometric accuracy of SCIAMACHY was specified prior to flight for the reflectance with 2-4\% (Bovensmann et al., 1999). These values were confirmed by comparisons with MERIS and Advanced Along-Track Scanning Radiometer (AATSR) measurements (Kokhanovsky et al., 2008) for the newest level1 data processor version 6.0 which was used in this study. However, for our study, only the relative calibration quality is relevant because we use the DOAS method which is only sensitive to differential structures (more details given in 2.2).

\subsection{Retrieval technique: PhytoDOAS}

In this study, the SCIAMACHY data acquired in nadir viewing geometry were analyzed using the Differential Optical Absorption Spectroscopy (DOAS) technique (Perner and Platt, 1979) to retrieve information on phytoplankton group distributions. DOAS exploits the sharp spectral features in backscattered solar spectra that are caused either by molecular absorption by atmospheric constituents (e.g. Richter et al., 2005), spectral re-distribution features as induced by the Ring effect (Vountas et al., 1998) or vibrational Raman Scattering (VRS) in ocean waters (Vassilkov et al, 2002; Vountas et al., 2003), or absorption features even from terrestrial plants (Wagner et al., 2007) and marine phytoplankton (Vountas et al., 2007). Raman scattering, from the interaction of the solar radiation with the rotation of air molecules in the atmosphere and vibrations of water, is an inelastic scattering and results in energy being transferred from shorter to longer wavelengths for this situation. This results in the infilling of the Fraunhofer lines in the backscattered radiation up-welling at the top of the atmosphere. The effect of inelastic scattering by $\mathrm{N}_{2}$ and $\mathrm{O}_{2}$ molecules in the atmosphere is called Ring effect and by liquid water in the ocean is called 
VRS; both have been observed in the backscattered radiation (Vountas et al., 1998; Vassilkov et al., 2002; Vountas et al., 2003). Therefore, DOAS retrievals from UV/visible spectra have to account for these effects which are treated as an effective absorber (named as pseudo-absorber) in the retrieval.

The first use of the DOAS method applied to satellite data (of Global Ozone Monitoring Experiment (GOME), the predecessor instrument to SCIAMACHY) was shown and described in detail by Burrows et al. (1999). Since the DOAS method is new to the oceanic remote sensing community, we briefly describe its application to derive information on diatoms and cyanobacteria global distributions.

The DOAS algorithm determines the amount of a molecular absorber along the observed optical light path by least square fitting a linear combination of reference absorption cross-section spectra of trace gases, a Ring reference spectrum (RING), the Vibrational Raman Scattering (VRS) spectrum and in our case the phytoplankton absorption (phyto).

That is,

$$
\begin{aligned}
& \tau(\lambda, s)=\ln \left(\mathrm{I}(\lambda, s) / \mathrm{I}_{0}(\lambda)\right) \\
& =\sum_{i} \sigma_{i}(\lambda) \times \mathrm{S}_{i}(s)+\sigma_{\mathrm{RING}} \times \mathrm{S}_{\mathrm{RING}}(s)+\sigma_{\mathrm{VRS}} \\
& \times \mathrm{S}_{\mathrm{VRS}}(s)+\sigma_{\text {phyto }} \times \mathrm{S}_{\text {phyto }}(s)-\sum_{k=0}^{n} a_{k} \lambda^{k}
\end{aligned}
$$

where, $\tau(\lambda, \mathrm{s})$ is the measured slant optical density, $I$ being the backscattered radiance, $I_{0}$ the extra-terrestrial irradiance, $\sigma_{i}(\lambda)$ the differential absorption cross section of the $i$ th atmospheric molecule at wavelength $\lambda$, and $\mathrm{S}_{i}(s)=\int_{s} \rho_{i} C(s)$ $d s$ is the integrated number density along the slant optical path $s$, which is mainly defined by the solar zenith angle and the viewing geometry of the instrument. A low order polynomial, $\sum_{k=0}^{n} a_{k} \lambda^{k}$, with typically $\mathrm{n} \leq 4$, is subtracted from the measured optical depth in Eq. (1) to remove broad-band structure resulting from the slowly varying component of the molecular absorption, Rayleigh and Mie scattering. A linear least squares regression with the $\mathrm{S}_{i}, \mathrm{~S}_{\mathrm{RING}}, \mathrm{S}_{\text {phyto }}, \mathrm{S}_{\mathrm{VRS}}$ and the regression coefficients $a_{k}$ as fitting parameters is carried out.

The optical density describes all the radiative contributions from atmosphere and water including multiple scattering and surface reflectance effects. Depending on the targeted absorber (in our case in the first fit the phytoplankton absorption and in the second fit the scattered electromagnetic radiation resulting from VRS), an optimal wavelength window is selected and all the relevant radiative contributions within this window are considered. The target quantities, S, are called slant column, scaling or fit factor and the crosssections $\sigma$ for each trace gas, the phytoplankton absorption, the Ring-Effect and VRS are fitted. S has units of molecule (mol) $\mathrm{cm}^{-2}$, whereas $S$ for phytoplankton, $S_{\text {phyto }}$ has units of chl-a $\mathrm{mg} \mathrm{m}^{-2}$ consistent with the units of its cross section.

SCIAMACHY provides both measurements, from the Earth surface and atmosphere backscattered Sun light $I$ and direct measurements of Sun light $I_{0}$. Only SCIAMACHY backscattered solar spectra under clear sky conditions taken at a solar zenith angle of below $60^{\circ}$ were considered for analysis. Absorption cross sections of relevant atmospheric absorbers have been measured in the laboratory and for the absorption by certain phytoplankton groups have been measured on natural samples. Pseudo-absorbers such as Ring and VRS have been modeled (more details below).

The DOAS technique is used to separate and thereby retrieve the higher frequency absorption structures from broadband. By taking the ratio between direct and backscattered solar spectra and accounting for broadband structures through the subtraction of a polynomial, it is to a first order approximation independent of the absolute calibration, and only requires an accurate relative calibration. However, the DOAS method will lead to error if the reference spectra used in the fit have spectral correlation, i.e. the fit algorithm will not be able to distinguish between similar spectral features. As a metric of fit quality, $X^{2}$ values are often used. These are defined as the square of the wavelength-integrated fit residual weighted with the square of the measurement error. Therefore, high $X^{2}$-values indicate poor fit quality.

Based on the method by Vountas et al. (2007) but modified in order to retrieve phytoplankton group biomass from SCIAMACHY data, the PhytoDOAS method uses two separate DOAS-fits in different wavelength windows for the same SCIAMACHY data set. This data set covered the time period 15 October to 14 November 2005 and 8 February to 19 March 2004 where also in-situ data were available (Sect. 2.3). The first DOAS-fit within the visible range yields the absorption strength of a specific phytoplankton group (Sect. 2.2.1). The second DOAS fit within the UV-A range is used to yield the VRS fit factor, which was exactly determined by the method described in Vountas et al. (2007). Using the results of both fits, the phytoplankton group biomass can be calculated (Sect. 2.2.2).

\subsubsection{Retrieval of differential absorption by selected phytoplankton groups}

The DOAS fit was applied to the global data set within the 429.0 to $495.0 \mathrm{~nm}$ spectral range, accounting for optical contributions of atmospheric trace gases, Ring effect, phytoplankton group absorption and the first eigenvector from the principle component analysis (PCA) which are all specified below. As described in Vountas et al. (2007), this first eigenvector of the PCA is attributed to small instrumental biases. In order to extract these biases, SCIAMACHY data within the wavelength range of 425 to $499 \mathrm{~nm}$ were analyzed by DOAS over a region with negligible amounts of absorption by phytoplankton including the fitting of the Ring effect and atmospheric absorbers, as specified below, but not phytoplankton. Then an eigenvector analysis by Principal Component Analysis (PCA) on the residuals of these regional DOAS fits was performed. The region selected for analyzing 
the residuals at $18^{\circ} \mathrm{S}$ to $28^{\circ} \mathrm{S}$ and $115^{\circ} \mathrm{W}$ to $125^{\circ} \mathrm{W}$ was chosen based on the criteria that both, cyanobacteria and diatoms, have very small absorption and the total phytoplankton biomass is below $0.05 \mu \mathrm{g} / \mathrm{l}$ (as described in Morel et al., 2007).

For fitting phytoplankton absorption, reference spectra specific for cyanobacteria and diatoms absorption obtained from absorption measurements at water samples from different regions in the Atlantic Ocean and characterized by pigment analysis (described in detail Sect. 2.3) were used. The retrieval accounted for differential absorptions of the trace constituents ozone, water vapor, $\mathrm{NO}_{2}, \mathrm{CHOCHO}$ and $\mathrm{O}_{4}$. Absorption cross sections were taken from Bogumil et al. (2003) for ozone, Burrows et al. (1998) for $\mathrm{NO}_{2}$, Greenblatt et al. (1990) for $\mathrm{O}_{4}$ and Volkamer et al. (2005) for CHO$\mathrm{CHO}$. For the so-called pseudo-absorber spectra, a ring spectrum after Vountas et al. (1998) was used. The VRS is irrelevant for the DOAS-fit of phytoplankton absorption and, therefore, was not considered in the fit of phytoplankton absorption.

\subsubsection{Retrieval of cyanobacteria and diatoms chl-a con- centrations from SCIAMACHY}

In order to convert the extracted SCIAMACHY fit factor or slant columns of phytoplankton absorption specific for diatoms or cyanobacteria into concentration expressed as $\mathrm{mg}$ chl-a/ $\mathrm{m}^{3}$, the information of the light penetration depth is needed. The fit factor $S_{\text {phyto }}$ is given in $\left[\mathrm{mg} \mathrm{chl}-\mathrm{a} / \mathrm{m}^{2}\right.$ ] which is a mass column. If the penetration depth $\delta$ of light for the wavelength window considered is known, this column can be converted into a chl-a concentration $C$ by the ratio:

$C=\frac{\mathrm{S}_{\text {phyto }}}{\delta}$

The VRS fit factor is assumed to have a linear relationship to the number of VRS scattering events along the optical path through the water. VRS serves as a proxy for the light penetration depth because a single VRS event is always accompanied by an elastic scattering process. The extraction of the fit factor $S_{V R S}$ from SCIAMACHY and its relation to backscattering coefficient $b_{b}$ after Morel (1988) and to $\delta$ is described in detail in Vountas et al. (2007). For the real situation the true $b_{b}$ can be approximated by scaling $b_{b}$ with the same factor as the VRS spectrum ( $\mathrm{S}_{\mathrm{VRS}}$ ). Since $\mathrm{S}_{\mathrm{VRS}}$ is assumed to represent the true $b_{b}$ for the phytoplankton absorption region, $\mathrm{S}_{\mathrm{VRS}}$ was converted from the wavelength window of the VRS DOAS-Fit ( 349.5 to $382 \mathrm{~nm}$ ) to the window of the phytoplankton DOAS-fit (429 to $495 \mathrm{~nm}$ ). This was achieved by the method of Bartlett et al. (2001). Finally, the modeled penetration depth, $\delta$, with

$\delta=\frac{1}{b_{b}}$

can be associated with the measured $\mathrm{S}_{\mathrm{VRS}} * b_{b}^{-1}$.

\subsection{In-situ measurements of phytoplankton absorption and composition}

For this study two absorption spectra measured on surface water samples from two different cruises (Antarctic cruise number 23 lag 3 (ANTXXI/3), ANTXXIII/1) with the research vessel RV "Polarstern" were chosen as representative spectra for two phytoplankton groups, namely diatoms and cyanobacteria. The decision for each representative spectrum is based on individual pigment composition determined by HPLC. Some of the other pigment samples taken during the two cruises were used later for comparisons to PhytoDOAS retrieval results.

The phytoplankton absorption was determined according to the method by Tassan and Ferrari (1995). In addition, for the ANTXXIII-1 cruise, the estimates of phytoplankton absorption were obtained from high spectral resolution measurements on the discrete water samples with a point-source integrating cavity absorption meter, PSICAM (Röttgers et al., 2005). For the analysis of pigment composition of water samples from both cruises, the samples were immediately filtered on GF/F (Whatman filters) and stored at $-80^{\circ} \mathrm{C}$ until analysis. The volume filtered was between one and three liters depending on the concentration of phytoplankton material in the water. The HPLC samples were measured as described by Hoffmann et al. (2006). The phytoplankton composition of the plankton community was classified into taxonomic groups using the CHEMTAX program (Mackey et al., 1996). The input matrices were chosen according to typical ratios for a given oceanic region. For the Southern Ocean cruise (ANTXXI/3) the matrix was taken from Wright et al. (1996) and for the subtropical and tropical cruise (ANTXXIII/1), the input matrix was taken from Veldhuis and Kraay (2004).

Two representative absorption spectra, of the two in the Atlantic Ocean in-situ measured phytoplankton groups, are shown in Fig. 1. The spectra were chosen from over 200 absorption spectra measured during the two Atlantic cruises. The selection was based on the samples absolute pigment composition determined with HPLC in addition to the taxonomical grouping by CHEMTAX. The spectra selected are in accordance with absorption measurements on various pure diatom and cyanobacteria monocultures (by Johnsen et al., 1994; S. Gehnke and R. Röttgers, personal communication, 2009). Absorption measurements on natural samples were preferred to use as reference spectra for satellite retrievals because cultures would be expected to differ from natural populations due to differences in pigment packaging, pigment composition, and other factors influencing absorption, for example, related to absorption due to artificial light source and nutrient conditions.

The first absorption spectrum selected as a reference spectrum for cyanobacteria was measured in a water sample taken from the ship's moonpool via a pump during the cruise ANTXXIII/ 1 on 30 October 2005 at $22.3^{\circ} \mathrm{N}$ and $20.3^{\circ} \mathrm{W}$ at 


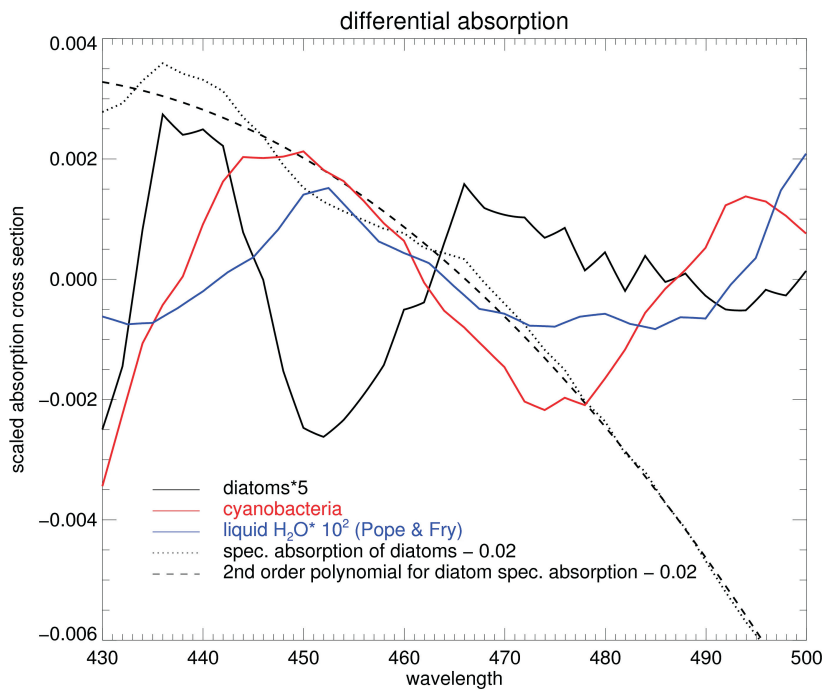

Fig. 2. Differential absorption (straight line) of the two in-situ measured phytoplankton absorption spectra shown in Fig. 1 and of pure sea water according to Pope and Fry (1997). For the diatoms also the specific absorption (in units of $\mathrm{m}^{-2} / \mathrm{mg}$ chl-a) with an offset of -0.02 (dotted line) and the associated 2 nd order polynomial with an offset of -0.02 (dashed line) is plotted.

12:50 GMT (further description of this cruise and the optical measurements are found in Stramski et al., 2008). The direct measurements using the PSICAM and the indirect measurements via the filtration method were in good agreement, but only the PSICAM method detected the absorption by phycoerythrine within the range of 530 to $570 \mathrm{~nm}$ (Fig. 1). The simplest explanation for this behavior is that these pigments were eliminated during the filtration process. The pigment composition via HPLC of the sample had as a diagnostic marker, only zeaxanthin, indicating that only cyanobacteria (including Prochlorococcus, according to the classification by Urbach et al., 1992) were present in the sample. The second absorption spectrum selected was measured in a water sample taken by a CTD rosette sampler during the EIFEX (ANTXXI/3) cruise on 14 March 2004 at $49.4^{\circ} \mathrm{S}$ and $2.1^{\circ} \mathrm{E}$ at 05:50 GMT (a further description of this cruise is in Hoffmann et al., 2006). The main marker pigments were fucoxanthin $(>1500 \mathrm{ng} / \mathrm{l})$ and chl-c2 $(950 \mathrm{ng} / \mathrm{l})$, both indicative of diatoms. Other marker pigments, indicative of various nanoflagellates, were present in trace amounts, e.g. 19but $(67 \mathrm{ng} / \mathrm{l}), 19$-hex $(65 \mathrm{ng} / \mathrm{l})$, peridinin $(60 \mathrm{ng} / \mathrm{l})$ and chl-b ( $24 \mathrm{ng} / \mathrm{l})$. The pigment data analyzed via CHEMTAX and verified by microscopic counts (Smetacek et al., 2005) are consistent with a population dominated mainly by diatoms ( $\sim 79 \%$ of chl-a), with the remainder of the community attributed to prymnesiophytes $(\sim 17 \%$, mainly Phaeocystis), dinoflagellates $(\sim 3 \%)$ and chlorophytes $(\sim 1 \%)$. Since diatoms were not only present in this sample, we refer to this as the diatom-like spectrum thereafter.
Within the DOAS analysis in order to perform the least square fit to the differential absorption of all relevant absorbers and to the low order polynomial, from each absorption spectrum a low order polynomial is subtracted. Figure 2 shows, as an example for the diatom-like specific absorption spectrum, the 2nd order polynomial and the specific differential spectrum for the wavelength range of $429 \mathrm{~nm}$ to $495 \mathrm{~nm}$ which was used in the PhytoDOAS retrieval. In addition, Fig. 2 shows also the differential spectra for the cyanobacteria sample and for the pure water absorption (taken from Pope and Fry, 1997). As seen in Fig. 2, the differential spectrum of the diatom-like spectrum shows significant differences in structure from the cyanobacteria and the pure water spectra, while the differential absorption of cyanobacteria correlates between 435 to $475 \mathrm{~nm}$ with pure water absorption. The correlation is described in the sense of orthogonality which means that the scalar product of the two spectra is not equal to zero. Therefore to be consistent, no separate liquid water fit was performed within both phytoplankton absorption fits and liquid water absorption was included with fitting the month specific eigenvector.

\section{Results}

\subsection{Phytoplankton absorption of cyanobacteria and di- atoms from SCIAMACHY}

Examples of the differential optical depths of the SCIAMACHY spectral fits from the two considered phytoplankton groups are shown in Fig. 3. In addition, the results of the in-situ measured differential phytoplankton spectrum (from Fig. 2) scaled with the fit-factor are plotted. For both major phytoplankton groups, the cyanobacteria and the diatomlike, there is a good agreement between the differential spectrum obtained from the PhytoDOAS-fit with SCIAMACHY satellite data and the in-situ measurement. The residuals of the same fit have very low values and low spectral structure (Fig. 4). These results support the conclusion that the PhytoDOAS method provides a reasonable retrieval of phytoplankton group specific absorption for the condition of this study.

The monthly average of the global distribution of the fit factor (absorption strength) of cyanobacteria during the Northern Hemispheric fall and Southern Hemispheric spring (October/November 2005) retrieved from SCIAMACHY data with PhytoDOAS using the phytoplankton absorption spectrum typical for cyanobacteria is shown in Fig. 5 (upper panel). Cyanobacteria absorption appears mainly in the warmer seas of the subtropics and tropics, e.g. in larger parts of the Pacific, the Arabian Sea and off the West-African coast. Gaps in this global map are either due to the presence of clouds or the absence of a significant SCIAMACHY result to the cyanobacteria absorption spectrum (which is interpreted as this group having a minor contribution to the 


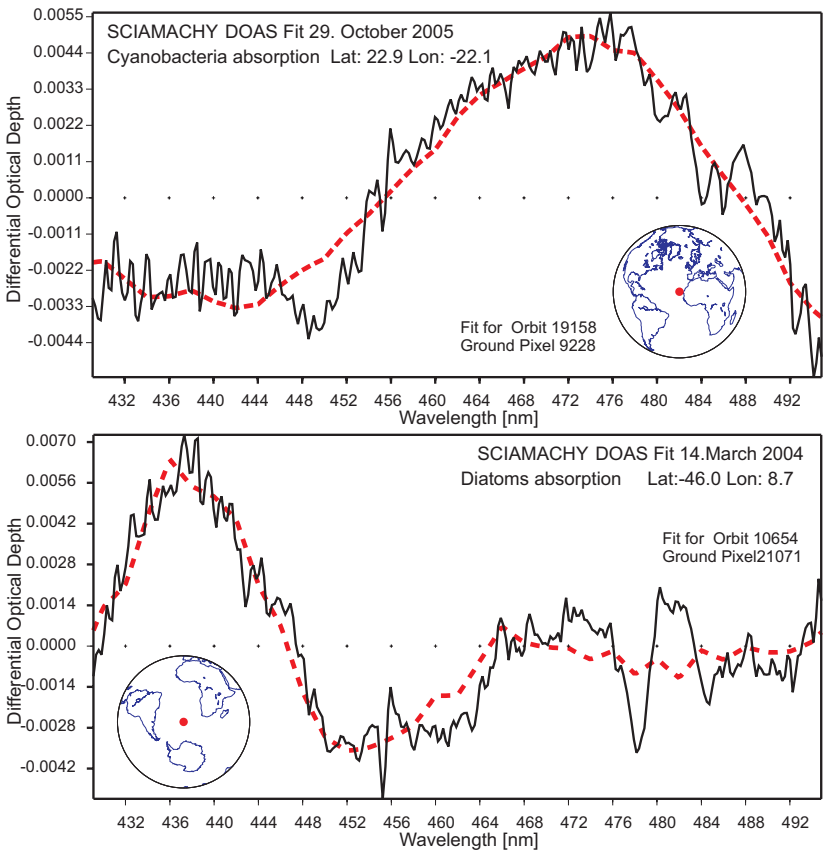

Fig. 3. Differential Optical Depth of a spectral PhytoDOAS fit with SCIAMACHY data (black) for a specific phytoplankton group (upper panel: for cyanobacteria and lower panel: for diatoms) using the phytoplankton group specific differential absorption cross sections from Fig. 2 and showing the scaled in-situ phytoplankton differential absorption (red) of the specific group. For the example in the upper panel the in-situ measurement for cyanobacteria (details described in Fig. 1) was taken and the SCIAMACHY measurement was within $20 \mathrm{~h}$ and $50 \mathrm{~km}$ of this in-situ measurement. For the example in the lower panel the in-situ measurement for a community dominated by diatoms (see details given in Fig. 1) was taken and the SCIAMACHY measurement was within $2 \mathrm{~h}$ and $200 \mathrm{~km}$ of the in-situ measurement (details described in Fig. 1).

observed optical density). The global distribution of the absorption strength of diatoms retrieved with PhytoDOAS from SCIAMACHY is shown in Fig. 5 (lower panel) for the same time period as Fig. 5 (upper panel). Results for this time of year show high absorption of diatoms in coastal areas around up-welling regions of the West-American and West-African coasts and in the Southern Ocean.

\subsection{Biomass of cyanobacteria and diatoms from SCIA- MACHY}

The monthly average of the global distribution of cyanobacteria biomass (expressed as chl-a conc.), for the same time period (October/November 2005) as shown in Fig. 5, retrieved from SCIAMACHY data with PhytoDOAS is presented in Fig. 6 (upper left panel). Cyanobacteria appear mainly in the warmer seas of the subtropics and tropics, e.g. in larger parts of the Pacific, the Arabian Sea and off the West-African coast. Calculations made by the NASA
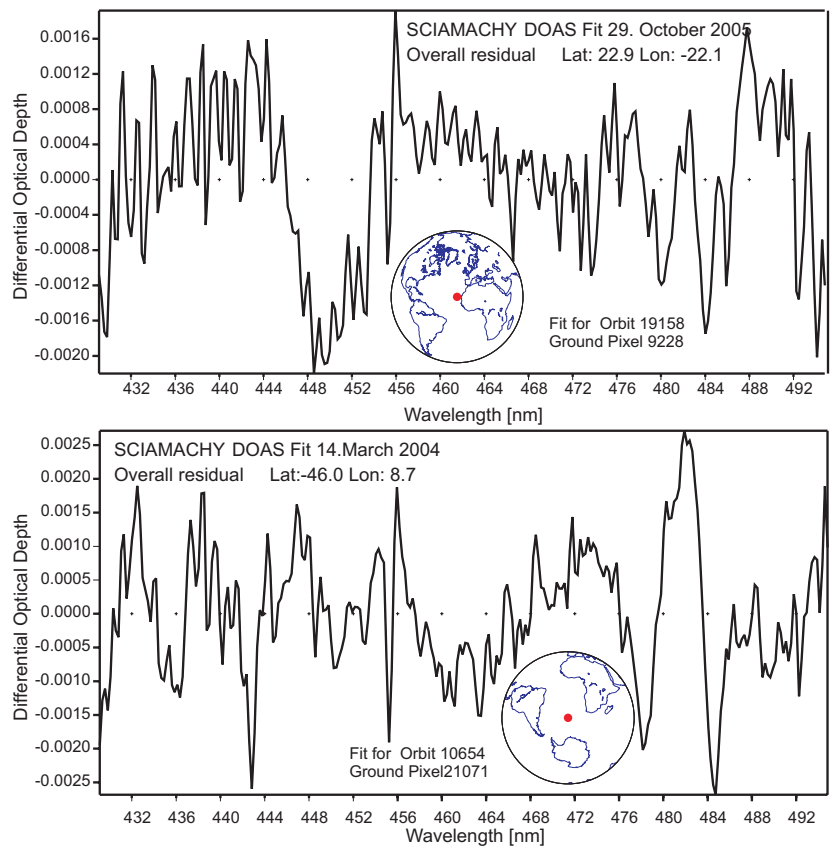

Fig. 4. Residuals of spectral DOAS fit with SCIAMACHY data for a specific phytoplankton group (upper panel: for cyanobacteria and lower panel: for diatom-like) for the same examples shown in Fig. 3.

Ocean Biochemical Model (NOBM) developed by Gregg and Casey (2007) of the global distribution of cyanobacteria for the same time period are shown in Fig. 6 (upper right panel). In order to better visualize the comparison between the PhytoDOAS analysis and NOBM, two areas of the global maps are shown in more detail: the tropical Atlantic in the middle panel and the South Atlantic in the lower panel. Overall, both analyses show in very similar regions the appearance of cyanobacteria (chl-a conc. $>0.01 \mu \mathrm{g} / \mathrm{l}$ ), but the tropical PhytoDOAS values show higher maximum values $(0.5 \mu \mathrm{g} / \mathrm{l})$ as compared to NOBM $(0.3 \mu \mathrm{g} / \mathrm{l})$.

Figure 7 shows, for the same time period as Fig. 6, the global distribution of diatoms biomass retrieved with PhytoDOAS from SCIAMACHY (upper left panel) and from calculations made for diatoms with the NOBM (upper right panel) which appear to be in good agreement on the overall range of values. Results of both analyses from ocean areas surrounding Japan (Fig. 7 middle panel) and from South Atlantic (Fig. 7 lower panel) show very similar quantitative distributions of diatoms. Both analyses show that during Northern Hemispheric fall and Southern Hemispheric spring diatoms are quite abundant and the dominant group in the Southern Ocean (below $32^{\circ} \mathrm{S}$ ) and in coastal areas around upwelling regions at the West-American and West-African coasts.

To evaluate the performance of the SCIAMACHY cyanobacteria and diatom biomass data, match-ups between 


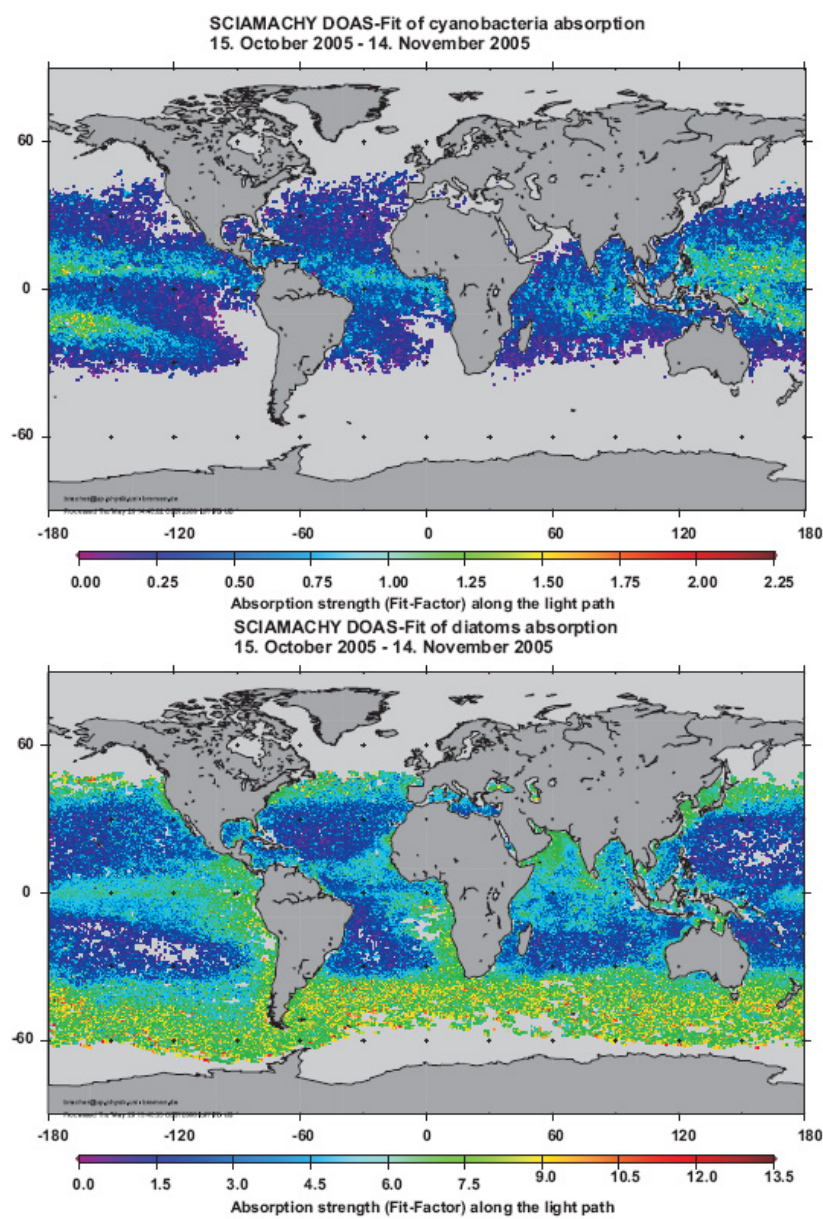

Fig. 5. Monthly average (from 15 October to 14 November 2005) of global distribution of cyanobacteria (upper panel) and diatoms (lower panel) obtained as "Strength of Absorption" (=Fit-Factor) by using PhytoDOAS with SCIAMACHY.

the in-situ measurements of these phytoplankton groups chla from the two Atlantic cruises described in Sect. 2.3 and SCIAMACHY retrievals were compared. The criteria for the match-ups were that in-situ samples were taken within $12 \mathrm{~h}$ of the SCIAMACHY measurement and within the SCIAMACHY pixel or the next adjacent one $(180 \mathrm{~km})$. Mean values for SCIAMACHY pixels collocated to the same insitu samples, and vice versa, were determined and are shown in Fig. 8. For the comparison of cyanobacteria and diatom biomass distributions only five match-ups each were identified. Compared to these collocated in-situ measurements and in contrast to the comparisons with NOBM, SCIAMACHY PhytoDOAS underestimated the cyanobacteria chl-a by $6 \%$ with a standard deviation of $44 \%$ and overestimated the diatom chl-a by $15 \%$ with a standard deviation of $31 \%$.

\section{Discussion and conclusions}

Extending and building on the work of Vountas et al. (2007), this study has used high spectrally resolved satellite data to retrieve for the first time quantitative information about two major phytoplankton functional types, cyanobacteria and diatoms. Our SCIAMACHY satellite maps on the distribution of cyanobacteria and diatoms show overall a good agreement with in-situ measurements on phytoplankton absorption and concentrations of these particular groups which are spatially and temporally collocated. SCIAMACHY fit results attributed to absorption by phytoplankton representative for cyanobacteria and those representatives for diatoms are of high quality having small residuals. First comparisons of these data with in-situ data indicate with certainty that the PhytoDOAS retrieval method is achieving plausible and realistic results. Furthermore, the global distribution of the data products for the phytoplankton types is in qualitative agreement with the calculations based on the NOBM.

Comparisons of our results so far are still preliminary as a thorough validation is difficult to perform at this stage. Insitu measurements are quite sparse in general, and they only provide punctual data points instead of an integral over the large surface footprint of an ocean color sensor $\left(\sim 1-9 \mathrm{~km}^{2}\right.$ and for SCIAMACHY $>30 \mathrm{~km}^{2}$ ). Nevertheless, these first comparisons to in-situ data indicate that the range of SCIAMACHY phytoplankton group chl-a is reasonable and plausible. Since the NOBM simulations combine global ocean color biomass data with global data sets on nutrient distributions, sea surface temperature and current conditions (Gregg et al., 2007) to calculate various PFTs, it certainly is not the tool to validate PFTs satellite retrievals. However, it does provide an independent assessment for evaluating the global performance of the SCIAMACHY PhytoDOAS method. Global comparisons of NOBM chl-a to SeaWiFS and MODIS show an agreement within $10 \%$ and with insitu measurements within $20 \%$, phytoplankton group relative abundances derived from NOBM compared to in-situ observations are on average within 25\% (Gregg and Casey, 2007). Global values of fit factors of absorption by a mixed phytoplankton community and of VRS determined from SCIAMACHY measurements have shown a correlation to MODIS chl-a below $1.0 \mu \mathrm{g} / \mathrm{l}$ with an uncertainty of around $30 \%$ to chl-a conc. (Vountas et al., 2007). As SeaWiFS and MODIS chl-a have an uncertainty of around 35\% themselves, the observed deviations found between SCIAMACHY PhytoDOAS and NOBM can be considered to be within the uncertainties of these methods. Comparison of SCIAMACHY PhytoDOAS diatom and cyanobacteria estimates to other methods retrieving information on PFTs from space is difficult for two reasons:

1. different time periods of the year were analyzed (Uitz et al., 2006; Aiken et al., 2007; Hirata et al., 2008; Raitsos et al., 2008), 

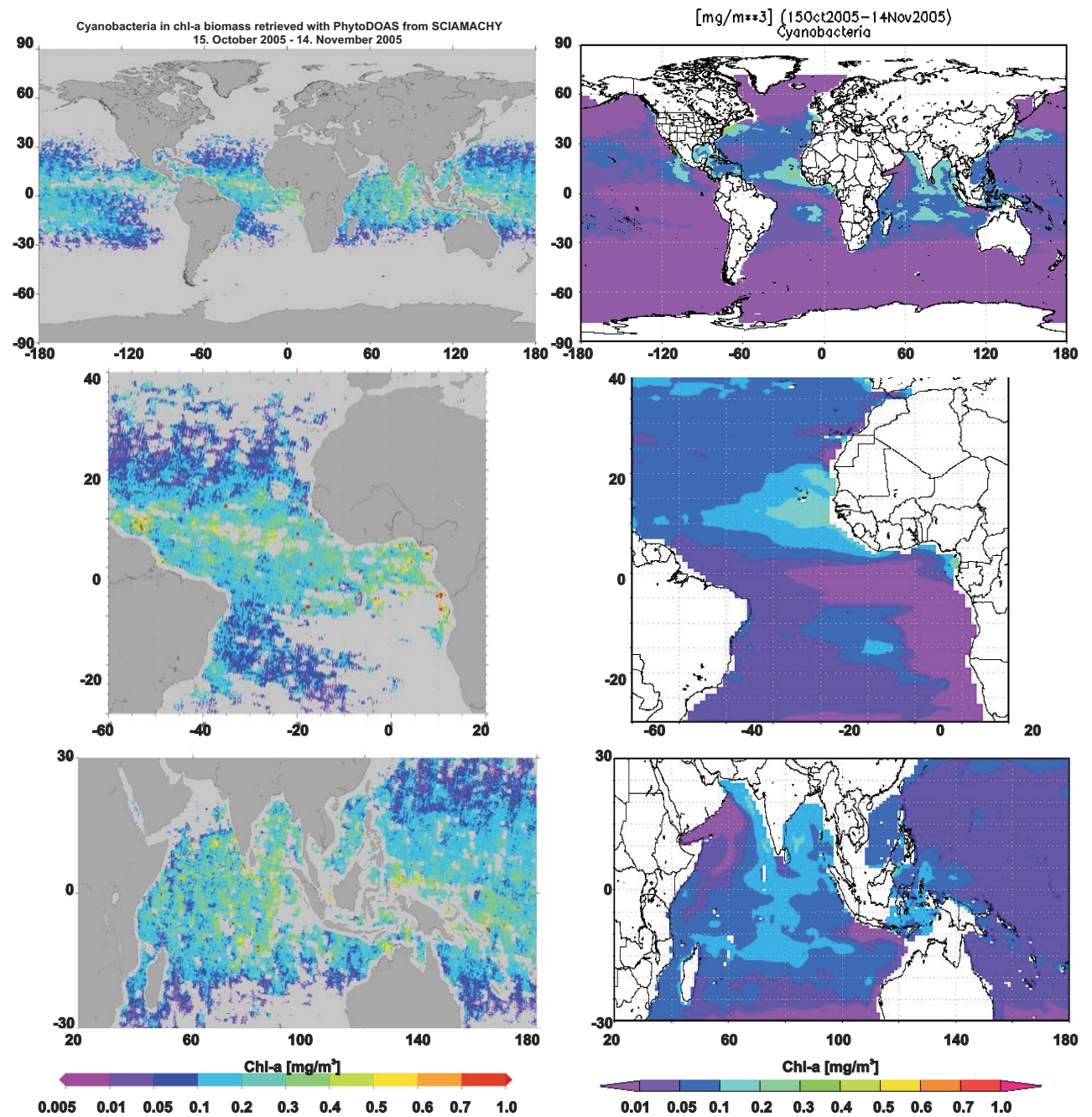

Fig. 6. Monthly average (from 15 October to 14 November 2005) global distribution in chl-a conc. of cyanobacteria determined by using the PhytoDOAS with SCIAMACHY data (left panel) and from calculations with the NOBM model by Gregg and Casey (2007) (right panel, figure from http://reason.gsfc.nasa.gov/OPS/Giovanni/ocean.modelDay.2.shtml). The upper panel shows the global distributions, extractions of the results are shown from the tropical Atlantic in the middle panel and from the tropical Indian Ocean and parts of the tropical Pacific in the lower panel.

2. in all methods except for Uitz et al. (2006), only the dominant groups were identified and no quantitative estimates were given.

Alvain et al. (2008) provide globally the mean monthly dominant PFTs determined by the PHYSAT method which did allow comparison with the PhytoDOAS results. These monthly means show for the months February-March and October-November similar distributions of cyanobacteria (identified here as the PFTs "Synechococcus-likecyanobacteria" and "Prochlorococcus") and diatoms in regions where SCIAMACHY PhytoDOAS identified the highest biomass for these two groups. Alvain et al. (2008) identified for October-November and February-March the dominance of diatoms in a circumpolar belt at $40^{\circ} \mathrm{S}-55^{\circ} \mathrm{S}$ and in the upwelling area off the coast of Peru. In addition to that in November, diatoms dominated the Benguela upwelling area. With the PhytoDOAS quantitative estimate and the NOBM estimates of diatoms, additional areas were identified to be rich in diatoms for the investigated months, such as the whole West-South American coast, the West-African coast and the region around Japan. Our findings on the distributions of diatoms, the NOBM and the PHYSAT method are also in accordance with previous studies based on in-situ sampling throughout the ocean. During Northern Hemispheric fall and Southern Hemispheric spring, diatoms have been shown to be quite abundant and the dominant group in the Southern Ocean and at the coastal areas around up-welling regions at the West-American and West-African coasts. This dominance and distribution of diatoms can be explained by their 

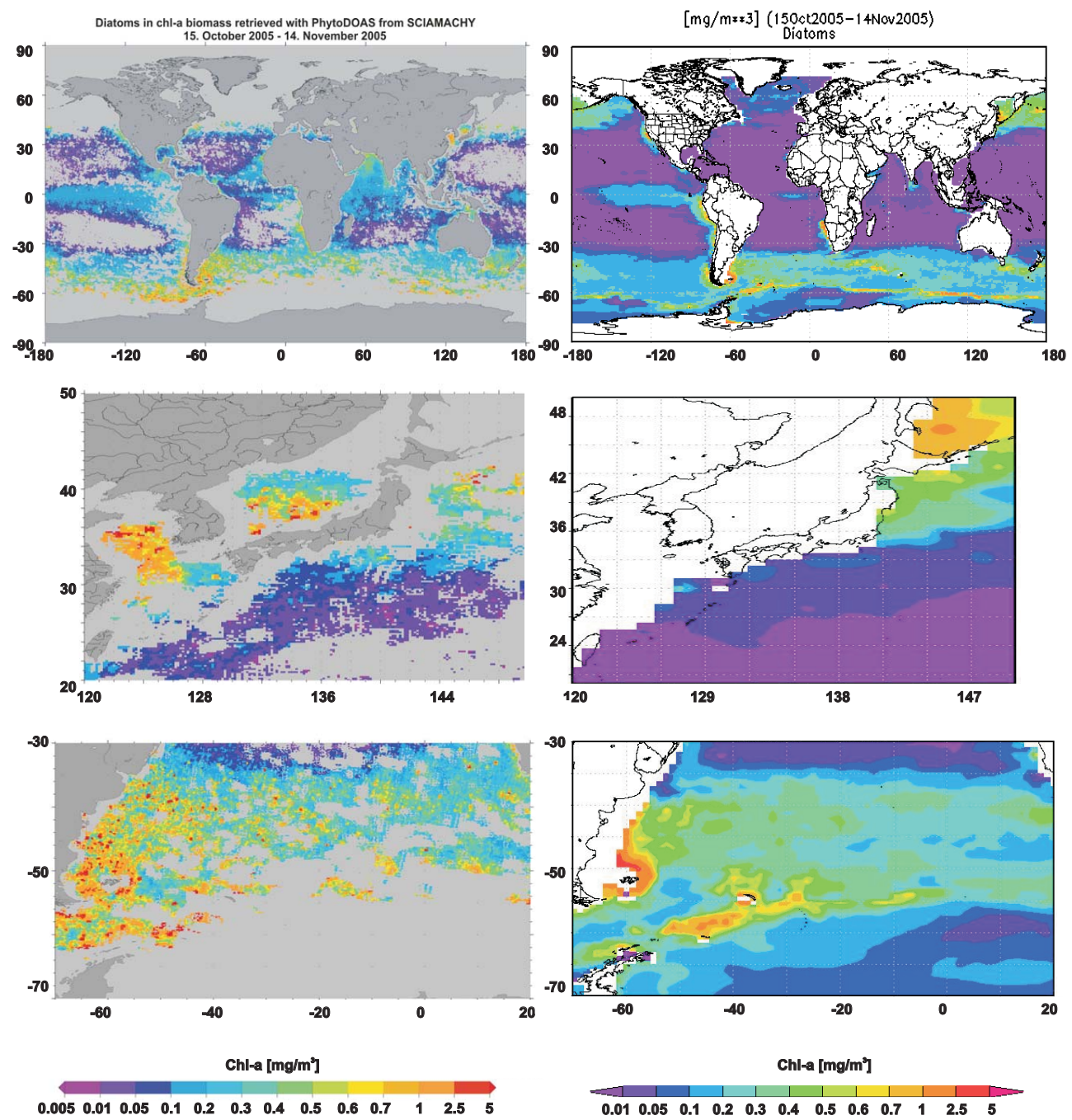

Fig. 7. Monthly average (from 15 October to 14 November 2005) global distribution in chl-a conc. of diatoms determined by using the PhytoDOAS with SCIAMACHY data (left panel) and from calculations with the NOBM model by Gregg and Casey (2007) (right panel, figure from http://reason.gsfc.nasa.gov/OPS/Giovanni/ocean.modelDay.2.shtml). The upper panel shows the global distributions, extractions of the results are shown from ocean areas surrounding Japan in the middle panel and from South Atlantic in the lower panel.

need for silicate. Therefore, diatoms flourish predominantly where there are sufficient nutrients (Treguer et al., 1995). Usually these areas are where cool and nutrient-rich waters come to the surface (mainly cool waters in the higher latitudes during spring-summer) and coastal areas. Also for the cyanobacteria, SCIAMACHY PhytoDOAS, PHYSAT by Alvain et al. (2008) and the NOBM show that they appear mainly in the warmer seas of the subtropics and tropics, e.g. in larger parts of the Pacific, the Arabian Sea and off the West-African coast, typical regions of low nutrients.

Diatoms are estimated to account for about $40 \%$ of the total marine primary production (Nelson et al., 1995). They are very important for biogeochemical cycles of carbon (C), nitrogen $(\mathrm{N})$, phosphorus $(\mathrm{P})$, silicon $(\mathrm{Si})$ and iron $(\mathrm{Fe})$ and referred to be the main drivers of export production (Smetacek,
1985). Within cyanobacteria there are two different strategies to circumvent the nutrient depletions. The unicellular and colony forming cyanobacteria are capable of using atmospheric dinitrogen gas $\left(\mathrm{N}_{2}\right)$ and catalyze it to ammonia. This introduces new formed nitrogen into the system (Zehr et al., 2001; La Roche et al., 2005). The other important cyanobacteria are the two small unicellar cyanobacteria Synechococcus and Prochlorococcus. These groups account for a large proportion of primary production in oligotrophic regions and are specialized in the nutrient limited conditions by their ability to use organic nitrogen (Zubkow et al., 2003). The communities dominated by these species are generally characterized by efficient recycling of nutrients and organic matter and relatively low export of organic carbon (Moran et al., 2004). Therefore, information about global 


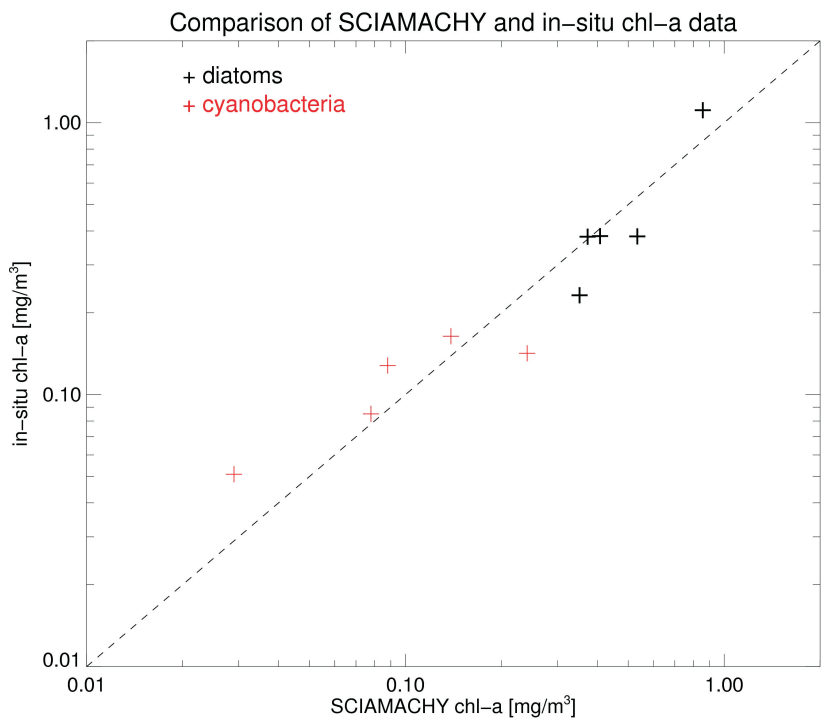

Fig. 8. Comparison of chl-a conc. from SCIAMACHY PhytoDOAS and from in-situ measurements at collocations (within $12 \mathrm{~h}$ and $180 \mathrm{~km}$ ) of cyanobacteria (red) and diatoms (black). Collocations for cyanobacteria are from October-November 2005 (no collocations in February-March 2004) and for diatoms from February-March 2004 (no collocations in October-November 2005).

quantitative distributions of diatoms and cyanobacteria are very useful for biogeochemical and ecosystem modeling. By using PhytoDOAS on SCIAMACHY data, it is possible for the first time to produce a near-real time picture in the open ocean of distributions in chl-a of these two phytoplankton groups.

The other methods used to identify PFTs from space (Alvain et al., 2005; Devred et al., 2006; Uitz et al., 2006; Aiken et al., 2007; Raitsos et al., 2008; Hirata et al., 2008) are empirical algorithms based on the training of a neural network (Raitsos et al., 2008), parameterization (all the other methods) of a large global or regional in-situ data set in order to yield from satellite chl-a or normalized water leaving radiances of the PFTs. Unexpected changes in the relationships between these parameters resulting from a regional or temporal sampling bias lead to a bias in the detection of PFTs. In contrast, the PhytoDOAS method exploits the information of the whole spectrum within the fitting wavelength window and discriminates cyanobacteria and diatoms by their characteristic absorption spectrum. Cyanobacteria and diatoms are quantified without assuming empirical relationships as in the case of other PFT methods. It is, therefore, possible to detect changes in the global distribution of these PFTs biomass which have not been foreseen. PhytoDOAS uses in its retrieval in-situ absorption spectra measurements from natural samples chosen to be representative for a certain group. Absorption spectra chosen to be representative for a certain group might also change the marker pigments in their quantity due to pigment packaging but probably not in their quality which is determining the differential signature. For the diatom-like spectrum, the fitting to this spectrum might be influenced in parts by the absorption of prymnesiophytes and dinoflagellates. Further adjustments of the fitting wavelengths window are necessary to overcome this issue to allow quantification of these other groups. By taking into account the details of the fitting wavelength window, PhytoDOAS enables a reliable atmospheric correction which, in other ocean color retrievals, is a significant source of error in the chl-a algorithm. In addition, PhytoDOAS simultaneously yields the depth to which the radiation penetrates. The PFT biomass derived is a depth-integrated mean over this depth. In comparison, the other PFT methods, besides Uitz et al. (2006), give estimates for the surface water only, without the knowledge how much chl-a from deeper layers influences the estimate. The limitations to our method are the rather coarse resolution of SCIAMACHY pixels with at best $30 \mathrm{~km}$ to $30 \mathrm{~km}$ and a global coverage, which is poorer than that of other ocean color sensors such as SeaWiFS, MERIS or MODIS. But, as stated by Aiken et al. (2007) phytoplankton distributions may be geographically distributed over 50 to $100 \mathrm{~km}$ and these structures persist over a few days.

The success of the SCIAMACHY PhytoDOAS shows a way to establish a global cyanobacteria and diatom biomass data base for the entire SCIAMACHY data set (starting in mid 2002). The analysis can also be applied to the similar sensor series GOME-2 which has a projected mission time extending to 2020 with a better temporal resolution. As pointed out above, PhytoDOAS will be evaluated in its capability to identify other PFTs and the large PhytoDOAS data base of PFTs and light penetration depth shall then be validated with ship-based measurements on phytoplankton samples and underwater light field. This additional biooptical satellite information obtained from PhytoDOAS shall be used for developing a global near-real time picture of the PFT distribution and an improved MERIS phytoplankton biomass retrieval. This new information shall be used as an input basis for primary production modelling and for developing improved atmospheric trace gas retrievals by accounting for the oceanic optical signal. The maps on the distribution of major phytoplankton groups and marine primary production are planned to be used within several climate change studies (e.g. identifying biogenic sources of greenhouse gas and short lived halogenated species, carbon cycle estimations).

Acknowledgements. The authors thank the crew, principal investigators and other scientists on board the RV Polarstern cruises ANTXXI-3 and ANTXXIII-1 for their support. We thank DLR and ESA for SCIAMACHY level-1 data. The images and data used to calculate the phytoplankton group distributions of cyanobacteria and diatoms with the NOBM were acquired using the GES-DISC Interactive Online Visualization ANd aNalysis Infrastructure (Giovanni) as part of the NASA's Goddard Earth Sciences (GES) Data and Information Services Center (DISC). Their service is 
gratefully acknowledged. We are grateful to Steven Lohrenz and one anonymous referee for their very constructive comments while reviewing this manuscript which further helped to improve the paper. Funding has been supplied by the Deutsche Forschungsgemeinschaft (DFG) via the project PASAT, the Helmholtz Impuls and Network Fond, and the Alfred-Wegener-Institute.

Edited by: A. Bricaud

\section{References}

Aiken, J., Fishwick, J. R., Lavender, S., Barlow, R., Moore, G. F., Sessions, H., Bernard, S., Ras, J., and Hardman-Mountford, N. J.: Validation of MERIS reflectance and chlorophyll during the BENCAL cruise October 2002: preliminary validation of new demonstration products for phytoplankton functional types and photosynthetic parameters, Int. J. Remote Sensing, 28, 497-516, 2007.

Alvain, S., Moulin, C., Danndonneau, Y., and Breon, F. M.: Remote Sensing of phytoplankton groups on case 1 waters from global SeaWiFS imagery, Deep Sea Res. I, 52, 1989-2004, 2005.

Alvain, S., Moulin, C., Danndonneau, Y., and Loisel, H.: Seasonal distribution and succession of dominant phytoplankton groups in the global ocean: A satellite view, Global Biogeochem. Cy., 22, GB3001, doi:10.1029/2007GB003154, 2008.

Bartlett, J., Voss, K., Sathendranath, S., and Vodacek, A.: Raman scattering by pure water and seawater, Appl. Opt., 37, 33243332, 1998.

Behrenfeld, M. J. and Falkowski, P. G.: Photosynthetic rates derived from satellite-based chlorophyll concentrations, Limnol. Oceanogr, 42, 1-20, 1997.

Bezy, J. L., Delwart, S., and Rast, M.: MERIS - a new generation of ocean-color sensor onboard ENVISAT, ESA Bulletin, ESA Directorate of Applications Programmes, ESTEC, Noordwijk, The Netherlands, 103, 48-56, 2000.

Bogumil, K., Orphal, J., Homann, T., Voigt, S., Spietz, P., Fleischmann, O. C., Vogel, A., Hartmann, M., Bovensmann, H., Frerik, J., and Burrows, J. P.: Measurements of molecular absorption spectra with the SCIAMACHY Pre-Flight Model: Instrument characterization and reference data for atmospheric remote sensing in the $230-2380 \mathrm{~nm}$ region, J. Photochem. Photobiol. A, 157, 167-184, 2003.

Bovensmann, H., Burrows, J. P., Buchwitz, M., Frerick, J., Noël, S., Rozanov, V. V., Chance, K. V., and Goede, A. H. P.: SCIAMACHY - Mission Objectives and Measurement Modes, J. Atmos. Sci., 56, 125-150, 1999.

Bracher, A. U. and Tilzer, M. M.: Underwater light field and phytoplankton absorbance in different surface water masses of the Atlantic Sector of the Southern Ocean, Polar Biol., 24, 687-696, 2001.

Brown, C. W. and Yoder, J. A.: Coccolithophorid blooms in the global ocean, J. Geophys. Res., 99, 7467-7482, 1994.

Buesseler, K. O.: The decoupling of production and particulate export in the surface ocean, Global Biogeochem. Cy., 12, 297-310, 1998.

Burrows, J. P., Hölzle, E., Goede, A. P. H., Visser, H., and Fricke, W.: SCIAMACHY - Scanning Imaging Absorption Spectrometer for Atmospheric Chartography, Acta Astronaut, 35, 445-451, 1995.
Burrows, J. P., Richter A., Dehn, A., Deters, S., Himmelmann, S., Voigt, S., and Orphal, J.: Atmospheric remote-sensing reference data from GOME: Part1. Temperature-tempendent absorption cross-section of NO2 in the 231-794 nm range, J. Quant. Spectrosc. Rad. T., 60, 1025-1031, 1998.

Burrows, J. P., Weber, M., Buchwitz, B., Rozanov, V., LadstätterWeißenmayer A., Richter, A., DeBeek, R., Hoogen, R., Bramstedt, K., Eichmann K.-U., and Eisinger, M.: The Global Ozone Monitoring Experiment (GOME): Mission concept and first scientific results,. J. Atmos. Sci., 56, 151-175, 1999.

Ciotti, A. M., Lewis, M. R., and Cullen, J. J., Assessment of the relationships between dominant cell size in natural phytoplankton communities and spectral shape of the absorption coefficient, Limnol. Oceanogr., 47, 404-417, 2002.

Cota, G. F., Harrison, W. G., Platt, T., Sathyendranath, S., and Stuart, V.: Bio-optical properties of the Labrador Sea, J. Geophys. Res., 108(C7), 3228, doi:10.1029/2000JC000597, 2003.

Devred, E., Sathyendranath, S., Stuart, V., Maas, H., Ulloa, O., and Platt, T.: A two-component model of phytoplankton absorption in the open ocean: Theory and applications, J. Geophys. Res., 111, C03011, doi:10.1029/2005JC002880, 2006.

Greenblatt, G. D., Orlando, J. J., Burkholder, J. B., and Ravishankara, A. R.: Absorption measurements of oxygen between 330 and 1140 nm, J. Geophys. Res., 95, 18577-18582, 1990.

Gregg, W. W., Ginoux, P., Schopf, P. S., and Casey, N. W.: Phytoplankton and iron: validation of a global three-dimensional ocean biogeochemical model, Deep Sea Res. II, 50, 3147-3169, 2003.

Gregg, W. W. and Casey, N. W.: Modeling coccolithophores in the global oceans, Deep Sea Res. II, 54(5-7), 447-477, 2007.

Hirata, T., Aiken, J., Smyth, T. J., Hardman-Mountford, N., and Barlow, R. G.: An absorption model to derive phytoplankton size classes from satellite ocean colour. Remote Sensing of Environment 112, 3153-3159, 2008.

Hoepffner, N. and Sathyendranath, S.: Effect of pigment composition on absorption properties of phytoplankton populations: implications for production in the open ocean, Mar. Ecol. Prog. Ser., 73, 11-23, 1991.

Hoffmann, L. J., Peeken, I., Lochte, K., Assmy, P., and Veldhuis, M.: Different reactions of Southern Ocean phytoplankton size classes to iron fertilization, Limnol. Oceanogr., 51(3), 12171229, 2006.

Jeffrey, S. W. and Vesk M.: Introduction to marine phytoplankton and their pigment signatures, in: Phytoplankton pigments in oceanography: Guidelines to modern methods, UNESCO, Paris, France, 33-84, 1997.

Johnsen, G., Samset, O., Granskog, L., and Sakshaug, E.: In vivo absorption characteristics in 10 classes of bloom-forming phytoplankton: Taxonomic characteristics and responses to photoadaptation by means of discriminant and HPLC analysis, Mar. Ecol. Prog. Ser., 105(1-2), 149-157, 1994.

Kirk, J. T. O.: Light and Photosynthesis in Aquatic Ecosystems, Cambridge University Press, 509 pp., 1994.

Kokhanovsky, A. A., Schreier M., and Hoyningen-Huene, W.: The comparison of spectral top-of-atmosphere reflectances measured by AATSR, MERIA and SCIAMACHY onboard ENIVISAT, IEEE Geosci. Remote Sens. Lett., 5(1), 53-56, 2008.

La Roche, J. and Breithbarth, E.: Importance of the diazotrophs as a source of new nitrogen in the ocean, J. Sea Res., 53, 67-91, 2005. 
Le Quere, C., Harrison, S. P., Prentice, C. I., Buitenhuis, E. T., Aumonts, O., Bopp, L., et al.: Ecosystem dynamics based on plankton functional types for global biogeochemistry models, Global Change Biol., 11, 2016-2040, doi:10.1111/j.13652486.2005.01004.x, 2005.

Mackey, M. D., Mackey, D. J., Higgins, H. W., and Wright, S. W.: CHEMTAX - a program for estimating class abundances from chemical markers: Application to HPLC measurements of phytoplankton, Mar. Ecol. Prog. Ser., 14, 265-283, 1996.

Moran, X. A. G., Fernandez, E., and Perez, V.: Size fractionated primary production, bacterial production and net community production in subtropical and tropical domains of the oligotrophic NE Atlantic in autumn, Mar. Ecol. Prog. Ser., 274, 17-29, 2004.

Morel, A.: Optical modeling of the upper ocean in relation to its biogeneous matter content (Case I waters), J. Geophys. Res., 93, 10749-10768, 1988.

Morel, A.: Consequences of a Synechococcus bloom upon the optical properties of oceanic (Case 1) waters, Limnol. Oceanogr., 42(8), 1746-1754, 1997.

Morel, A., Gentili, B., Claustre, H., Babin, M., Bricaud, A., Ras, J., and Tieche F.: Optical Properties of the "clearest" natural waters, Limnol. Oceanogr., 52(1), 217-229, 2007.

Moore, K. J., Doney, S. C., and Lindsay, K.: Upper ocean ecosystem dynamics and iron cycling in aglobal three-dimensional model, Global Biogeochem. Cy., GB4028, doi:10.1029/2004GB002220, 2004.

Nelson, D. M., Treguer, P., Brzezinski, M. A., Leynaert, A., and Queguiner, B.: Production and dissolution of biogenic silica in the ocean: Revised global estimates, comparison with regional data and relationship to biogenic sedimentation, Global Biogeochem. Сy., 9, 359-372, 1995.

O'Reilly, J. E., Maritorena, S., Mitchell, B. G., Siegel, D. A., Carder, K. L., Garver, S. A., et al.: Ocean color algorithms for SeaWiFS, J. Geophys. Res., 103, 24937-24953, 1998.

O'Reilly, J. E., Maritorena, S., Siegel, D., O’Brien, M. C., Toole, D., et al.: Ocean color chlorophyll a algorithms for SeaWiFS, OC2, and OC4: Version 4, in: SeaWiFS Postlaunch Technical Report Series, edited by: Hooker, S. B. and Firestone, E. R., SeaWiFS Postlaunch Calibration and Validation Analyses, Part 3. NASA, Goddard Space Flight Center, Greenbelt, Maryland, USA, 11, 9-23, 2000.

Perner, D. and Platt, U.: Detection of nitrious acid in the atmosphere by differential optical absorption, Geophys. Res. Lett., 93, 917920, 1979.

Pope, R. M. and Fry, E. S.: Absorption spectrum (380-700 nm) of pure water. II. Integrating cavity measurements, Appl. Opt., 36, 8710-8723, 1997.

Raitsos, D. E., Lavender, S. J., Maravelias, C. D., Haralambous, J., Richardson, A. J., and Reid, P. C.: Identifying four phytoplankton functional types from space: An ecological approach. Limnology and Oceanography, 53(2), 605-613, 2008.

Richter, A., Burrows, J. P., Nüß, H., Granier, C., and Niemeier, U.: Increase in tropospheric nitrogen dioxide over China observed from space, Nature, 437, 129-132, 2005.

Röttgers, R., Schönfeld, W., Kipp, P.-R., and Doerffer, R.: Practical test of a point-source integrating cavity absorption meter: the performance of different collector assemblies, Appl. Opt., 44(26), 5549-5560, 2005.

Sathyendranath, S., Lazzara, L., and Prieur, L.: Variations in spectral values of specific absorption of phytoplankton, Limnol. Oceanogr., 32, 403-415, 1987.

Sathyendranath, S., Watts, L., Devred, E., Platt, T., Caverhill, C., and Maass, H.: Discrimination of diatoms from other phytoplankton using ocean-colour data, Mar. Ecol. Prog. Ser., 272, 59-68, 2004.

Smetacek, V.: Role of sinking in diatom life-history cycles: ecological, evolutionary and geological significance, Mar. Biol., 84, 239-251, 1985.

Smetacek, V., Bathmann, U., Helmke, E. (eds.): The expeditions ANTARKTIS XXI/3-4-5The expeditions ANTARKTIS XXI/34-5 of the research vessel "Polarstern" in 2004, Reports on polar and marine research, 500, 302 pp., 2005.

Stramski, D., Reynolds, R. A., Babin, M., Kaczmarek, S., Lewis, M. R., Röttgers, R., Sciandra, A., Stramska, M., Twardowski, M. S., Franz, B. A., and Claustre, H.: Relationships between the surface concentration of particulate organic carbon and optical properties in the eastern South Pacific and eastern Atlantic Oceans, Biogeosciences, 5, 171-201, 2008,

http://www.biogeosciences.net/5/171/2008/.

Subramaniam, A., Brown, C. W., Hood, R. R., Carpenter, E. J., and Capone, D. G.: Detecting Trichodesmium blooms in SeaWiFS imagery, Deep Sea Res. II, 49, 107-121, 2002.

Tassan, S. and Ferrari, G. M.: An alternative approach to absorption measurements of aquatic particles retained on filters, Limnol. Oceanogr., 40, 1358-1368, 1995.

Treguer, P., Nelson, D. M., Van Bennekom, A. J., Demaster, D. J., Leynaert, A., and Queguiner, B.: The silica balance in the world ocean: A reestimate, Science, 268, 375-379, 1995.

Uitz, J., Claustre, H., Morel, A., and Hooker, S. B.: Vertical distribution of phytoplankton communities in open ocean: An assessment based on surface chlorophyll, J. Geophys. Res., 111, CO8005, doi:10.1029/2005JC003207, 2006.

Urbach, E., Robertson, D. L., and Chisholm, S. W.: Multiple evolutionary origins of prochlorophytes within the cyanobacterial radiation, Nature, 355, 267-270, 1992.

Vasilkov, A. P., Joiner, J., Gleason, J., and Bhartia, P.: Ocean Raman scattering in satellite backscatter UV measurements, Geophys. Res. Lett., 29, 1837-1840, 2002.

Veldhuis, M. J. W. and Kraay, G. W.: Phytoplankton in the subtropical: towards a better assessment of biomass and composition, Deep-Sea Res. I, 51, 507-530, 2004.

Volkamer, R., Spietz, P., Burrows, J. P., and Platt, U.: Highresolution absorption cross-section of glyoxal in the UV-vis and IR spectral ranges, J. Photochem. Photobiol. A, 172, 35-46, 2005.

Vountas, M., Rozanov, V. V., and Burrows J. P.: Ring Effect: Impact of rotational Raman scattering on radiative transfer in Earth's Atmosphere, J. Quant. Spectr. Rad. T., 6, 943-961, 1998.

Vountas, M., Richter, A., Wittrock, F., and Burrows, J. P.: Inelastic scattering in ocean water and its impact on trace gas retrievals from satellite data, Atmos. Chem. Phys., 3, 1365-1375, 2003, http://www.atmos-chem-phys.net/3/1365/2003/.

Vountas, M., Dinter, T., Bracher, A., Burrows, J. P., and Sierk, B.: Spectral Studies of Ocean Water with Space-borne Sensor SCIAMACHY using Differential Optical Absorption Spectroscopy (DOAS), Ocean Sci., 3, 429-440, 2007, http://www.ocean-sci.net/3/429/2007/.

Wagner, T., Beirle, S., Deutschmann, T., Grzegorski, M., and Platt, 
U.: Satellite monitoring of different vegetation types by differential optical absorption spectroscopy (DOAS) in the red spectral range, Atmos. Chem. Phys., 7, 69-79, 2007, http://www.atmos-chem-phys.net/7/69/2007/.

Waterbury, J. W., Watson, S. W., Valois, F. W., and Franks, D. G.: Biological and Ecological Characterization of the marine unicellular Cyanobacterium Synechococcus, Canad. Bull. Fish. Aquat. Sci., 214, 71-120, 1986.

Wright, S. W., Thomas, D. P., Marchant, H. J., et al.: Analysis of phytoplankton of the Australian sector of the Southern Ocean: Comparisons of microscopy and size frequency data with interpretations of pigment HPLC data using the "CHEMTAX" matrix factorisation program, Mar. Ecol. Prog. Ser., 144, 285-298, 1996.
Zehr, J. P., Waterbury, J. B., Turner, P. J., Montoya, J. P., et al.: Unicellular cyanobacteria fix $\mathrm{N}_{2}$ in the subtropical North Pacific Ocean, Nature, 412, 635-638, 2001.

Zubkov, M. V., Fuchs, B. M., Tarran, G. A., Burkill, P. H., and Amann, R.: High rate of uptake of organic nitrogen compounds by Prochlorococcus cyanobacteria as a key to their dominance in oligotrophic oceanic waters, Appl. Environ. Microb., 69, 12991304, 2003. 